\title{
Reactive Oxygen Intermediates Increase Vascular Endothelial Growth Factor Expression In Vitro and In Vivo
}

\author{
Masatoshi Kuroki, ${ }^{\star \ddagger}$ Emile E. Voest, ${ }^{\star}$ Shiro Amano, ${ }^{\star \ddagger}$ Laurens V. Beerepoot, ${ }^{\star \S}$ Seiji Takashima, ${ }^{\star}$ Michael Tolentino, ${ }^{\star \ddagger}$ \\ Rosa Y. Kim, ${ }^{\ddagger}$ Richard M. Rohan, ${ }^{\star}$ Kathryn A. Colby, ${ }^{\ddagger}$ Kiang-Teck Yeo, ${ }^{\|}$Anthony P. Adamis ${ }^{\star \ddagger}$ \\ *Department of Surgery, Children’s Hospital, Boston, Massachusetts 02115; ${ }^{\ddagger}$ Department of Ophthalmology, Massachusetts Eye and Ear \\ Infirmary, Boston, Massachusetts 02114; ${ }^{\S}$ Department of Internal Medicine, University Hospital of Utrecht, 3508 GA Utrecht, The \\ Netherlands; and $\|^{D}$ epartment of Pathology, Beth Israel Hospital, Harvard Medical School, Boston, Massachusetts 02115
}

\begin{abstract}
Elevated vascular endothelial growth factor (VEGF) levels are required for ocular and tumor angiogenesis in animal models. Ischemic hypoxia is strongly correlated with increased VEGF expression in these systems and is considered a physiologically relevant stimulus. Because ischemic hypoxia is often followed by reperfusion and reactive oxygen intermediate (ROI) generation, we examined the potential role of ROI in the control of VEGF gene expression. Human retinal pigment epithelial cells exposed to superoxide or hydrogen peroxide rapidly increased VEGF mRNA levels. Superoxide-associated mRNA increases were dose dependent, blocked by antioxidants, and associated with elevated VEGF protein levels in conditioned media. Increases in VEGF mRNA levels were also observed in cultured human melanoma and rat glioblastoma cells with superoxide or hydrogen peroxide. Cycloheximide prevented the ROIassociated increases in VEGF mRNA. Transcriptional inhibition with actinomycin $D$ revealed an inducible increase in VEGF mRNA half-life, but nuclear run-on experiments showed no increase in VEGF transcriptional rate. Reoxygenation of human retinal pigment epithelial cells in vitro and ocular reperfusion in vivo increased retinal VEGF mRNA levels. Antioxidants prevented the reperfusion-associated VEGF mRNA increases in retina. We conclude that ROIs increase VEGF gene expression in vitro and during the reperfusion of ischemic retina in vivo. The ROI-associated increases are mediated largely through increases in VEGF mRNA stability. (J. Clin. Invest. 1996. 98:16671675). Key words: angiogenesis $\bullet$ ischemia $\bullet$ vascular permeability • eye • tumor
\end{abstract}

Presented in part at the 1995 Association for Research in Vision and Ophthalmology (ARVO) Meeting, Ft. Lauderdale, FL on 14-19 May 1995.

Address correspondence to Anthony P. Adamis, Massachusetts Eye and Ear Infirmary, 243 Charles Street, Boston, MA 02114. Phone: 617-573-3529; FAX: 617-573-3152; E-mail: adamis@a1.tch. harvard.edu

Received for publication 8 May 1995 and accepted in revised form 9 August 1996.

J. Clin. Invest.

(c) The American Society for Clinical Investigation, Inc.

0021-9738/96/10/1667/09 \$2.00

Volume 98, Number 7, October 1996, 1667-1675

\section{Introduction}

Recent data implicate the secreted angiogenic peptide vascular endothelial growth factor (VEGF, ${ }^{1}$ also known as vascular permeability factor; reference 1 ) in the pathogenesis of ocular and tumor angiogenesis (2-10). Studies in animal models (2-4) and humans (8-10) have revealed a strong temporal and spatial correlation between VEGF expression and angiogenesis. The inhibition of VEGF bioactivity in animal models has prevented angiogenesis, demonstrating the requirement for VEGF in certain models of ocular and tumor angiogenesis $(2,3,5,11)$.

The term "vascular endothelial growth factor" refers to up to four homologous angiogenic polypeptides derived through the alternative splicing of mRNA $(12,13)$. The VEGF isoforms are secreted endothelial-specific mitogens with potent angiogenic and vascular permeability-enhancing actions in vivo (14, 15). The isoforms differ in their binding affinity for heparin, potentially facilitating extracellular spatial targeting (16).

Multiple factors increase VEGF expression in vitro. They include various cytokines (17), cobalt and nickel (18), phorbol esters (19), prostaglandins (20), and steroid hormones (21). The physiological relevance of these stimuli in vivo is not completely known. Hypoxia is a potent stimulus for increased VEGF expression in vitro (22) and ischemic hypoxia is spatially and temporally correlated with VEGF expression and angiogenesis in vivo $(22,23)$. For these reasons, ischemic hypoxia is believed to be a physiologically relevant stimulus for VEGF gene expression $(2,3,5)$.

Ischemic hypoxia is often followed by reperfusion and the generation of reactive oxygen intermediates (ROI). Ischemic diabetic retinal vascular occlusion, resulting from activated granulocytes and monocytes (24), is reversible and reperfusion has been documented angiographically in diabetic eyes (25). Elevated levels of ROI reaction products have been directly correlated with neovascularization in human (26) and rat (27) diabetic eyes, and in eyes with retinopathy of prematurity (28). Both ocular pathologies are strongly correlated with increased VEGF gene expression (8, 9, 29-31). In tumors, elevated interstitial pressures and altered blood viscosity (32) resulted in large areas of ischemia and reperfusion. This mechanism, together with ROI-producing inflammatory cells (33) may be responsible for the high ROI levels that are present in some tumors $(34,35)$.

1. Abbreviations used in this paper: Act $\mathrm{D}$, actinomycin D; DMTU, $N, N$ '-dimethylthiourea; DTT, dithiothreitol; ROI, reactive oxygen intermediates; RPE, retinal pigment epithelial; SSPE, sodium chloride sodium phosphate EDTA buffer; TPA, 12- $O$-tetradecanoylphorbol-13 acetate; VEGF, vascular endothelial growth factor; $\mathrm{X}$, xanthine; $\mathrm{XO}$, xanthine oxidase. 
Since ROI are strongly associated with the reperfusion of ischemic tissue and angiogenesis, we examined the potential role of ROI in the control of VEGF gene expression.

\section{Methods}

Reagents. Xanthine, xanthine oxidase, hydrogen peroxide, cycloheximide, catalase, superoxide dismutase, $N, N^{\prime}$-dimethylthiourea, dithiothreitol, ethylenediaminetetraacetic acid, NP-40, 12- $O$-tetradecanoylphorbol-13 acetate (TPA), Dulbecco's modified Eagle's media and actinomycin D were obtained from Sigma Chemical Co. (St. Louis, MO). RNAzol B was obtained from Biotecx Laboratories, Inc. (Houston, TX) and dextran sulfate and heparan sepharose from Pharmacia Fine Chemials (Uppsala, Sweden). MMAN melanoma cells and C6 glioblastoma cells were obtained from the American Tissue Culture Collection (Rockville, MD), and fetal calf serum from HyClone (Logan, UT). Bovine capillary endothelial cells were kindly supplied by Catherine Butterfield from Dr. Judah Folkman's laboratory (Children's Hospital, Boston, MA). Penicillin-streptomycin-glutamine was obtained from GIBCO BRL (Grand Island, NY) and plasticware from Falcon Labware, Becton Dickinson \& Co. (Franklin Lakes, NJ). Nylon filters were obtained from Gene Screen Plus, New England Nuclear (Boston, MA) and the random primed DNA labeling kits from Boehringer Mannheim Corp. (Indianapolis, IN). $\left[\alpha{ }^{32} \mathrm{P}\right]$ deoxyCTP, $\left[\alpha-{ }^{32} \mathrm{P}\right]$ deoxy-UTP, and $\left[{ }^{3} \mathrm{H}\right]$ thymidine were obtained from New England Nuclear, and the hypoxic incubation chambers from Billups-Rothenberg (Del Mar, CA). Maxisorp microtiter wells were obtained from Nunc, Inc. (Naperville, IL) and $\beta$-diketone from Pharmacia LKB Nuclear (Gaithersburg, MD). Human recombinant VEGF was obtained from R \& D Systems, Inc. (Minneapolis, MN). Densitometry was performed with an IS-1000 Digital Imaging System from Alpha Inotech Corp. (Torrence, CA) using version 1.97 software.

Cell culture. Human retinal pigment epithelial (RPE) cells were immortalized through the stable integration of a cytomegalovirusdriven SV-40 large T-antigen expression cassette and cultured on noncoated plates as previously described (36). The cells contain pigment, grow in a monolayer and increase VEGF mRNA during hypoxia in a manner identical to the parent cell line (36). MMAN melanoma cells and C6 glioblastoma cells were cultured on $1.5 \%$ gelatinized plates. All cell lines were maintained until experimentation in DMEM containing $10 \%$ heat-inactivated fetal calf serum and $100 \mathrm{U} / \mathrm{ml}$ penicillin, $100 \mathrm{mg} / \mathrm{ml}$ streptomycin, $2 \mathrm{mM}$ L-glutamine. Cells were plated into six-well plastic dishes and used for experiments when they reached $80-100 \%$ confluence. Fresh serum-free media were placed on the cells $12 \mathrm{~h}$ before experiments. All reagents were added directly to the wells in a volume of $100 \mu \mathrm{l}$ DMEM. Each condition was prepared in triplicate, and the experiments were carried out at least three times with reproducible results.

RNA isolation and Northern blot analysis. Total RNA was isolated from cultured cells and rabbit retinas by the method of Chomczynski and Sacchi (37). RNA (15 $\mu \mathrm{g})$ was electrophoresed through a $1 \%$ agarose-formaldehyde gel and transferred to nylon filters. The filters were prehybridized in buffer containing $50 \%$ deionized formamide, $5 \times$ SSPE (sodium chloride sodium phosphate EDTA buffer), $5 \times$ Denhardt's solution, $0.5 \%$ SDS, $10 \%$ dextran sulfate, and denatured salmon sperm DNA $(100 \mu \mathrm{g} / \mathrm{ml})$ and hybridized at $42^{\circ} \mathrm{C}$ in fresh buffer without salmon sperm DNA. The hybridization buffer contained either a 520-bp NcoI/BglII fragment of the human VEGF cDNA or a 575-bp fragment encompassing the entire coding region of the mouse VEGF cDNA. The blots were stripped and reprobed with a 400-bp fragment encompassing the $3^{\prime}$ untranslated region of the human $\beta$-actin cDNA. The cDNA probes were labeled with a random primed DNA labeling kit using $\left[\alpha{ }^{32} \mathrm{P}\right]$ deoxy-CTP. Filters were washed twice in $2-0.5 \times$ SSPE, $0.1 \%$ SDS for varying times and at increasing temperatures. The washes were titrated for maximum signal to noise ratio. The hybridized and washed filters were exposed to X-Omat AR x-ray film (Eastman Kodak Co., Rochester, NY) with an intensifying screen at $-70^{\circ} \mathrm{C}$ for $12-72 \mathrm{~h}$. Densitometry was performed on all blots and normalized to the corresponding actin signal for each lane.

Hypoxia/reoxygenation. $12 \mathrm{~h}$ after changing to serum-free media, RPE cells were placed in a sealed chamber and exposed to continuous hypoxia $\left(5 \% \mathrm{CO}_{2}, 1 \% \mathrm{O}_{2}\right.$, and $\left.94 \% \mathrm{~N}_{2}\right)$ for $16 \mathrm{~h}$, and then exposed to normoxia $\left(5 \% \mathrm{CO}_{2}, 21 \% \mathrm{O}_{2}\right.$, and $\left.74 \% \mathrm{~N}_{2}\right)$ for varying amounts of time as previously described (36).

Actinomycin D transcriptional inhibition. RPE cells were pretreated for $60 \mathrm{~min}$ with actinomycin-D (Act D, $5 \mu \mathrm{g} / \mathrm{ml}$ ) followed by continued Act D exposure \pm Xanthine (X), $500 \mu \mathrm{M}$; Xanthine Oxidase (XO), $20 \mathrm{mU} / \mathrm{ml}$. Total RNA was collected at the indicated time points and processed as described above.

Nuclear run-on analysis of transcription. Transcriptional activation of the VEGF gene in confluent cultures of the RPE was examined by run-on analysis after ROI or phorbol ester (TPA; $100 \mathrm{nM}$ ) treatment of the cells for designated times as previously described (36). Cells and all reagents were kept on wet ice or at $4^{\circ} \mathrm{C}$ throughout the duration of the experiment. Cells $\left(5 \times 10^{7} /\right.$ condition $)$ were washed with ice-cold PBS and nuclei were directly scrape-isolated into NP-40 lysis buffer (10 mM Tris, $\mathrm{pH} 7.4,10 \mathrm{mM} \mathrm{NaCl}, 3 \mathrm{mM}$ $\left.\mathrm{MgCl}_{2}\right), 5 \% \mathrm{NP}-40$ (vol/vol). Cells were pelleted at $300 \mathrm{~g}$ and gently resuspended in $20 \mathrm{ml}$ lysis buffer. Cell membranes were disrupted by 15 strokes of a prechilled Dounce homogenizer (type 'B' loose pestle). Nuclei were isolated by centrifugation $(300 \mathrm{~g})$ and washed in $50 \mathrm{vol}$ wash buffer (lysis buffer with $0.025 \%$ NP-40). After centrifugation, pelleted nuclei were resuspended in freeze buffer (20 mM Tris, $\mathrm{pH} 8.0$, $75 \mathrm{mM} \mathrm{NaCl}, 0.5 \mathrm{mM}$ EDTA, $1 \mathrm{mM}$ DTT, and 50\% glycerol), an aliquot examined by microscopy to confirm homogeneity and integrity of the preparation and the remaining samples were flash frozen in liquid $\mathrm{N}_{2}$ at a concentration of $2-3 \times 10^{8}$ nuclei $/ \mathrm{ml}$, and stored at $-80^{\circ} \mathrm{C}$. RNA synthesis in vitro was performed in the presence of $\sim 2 \times 10^{7}$ nuclei in a reaction mixture of $50 \mathrm{mM}$ Tris, $\mathrm{pH} 8.0,5 \mathrm{mM} \mathrm{MgCl}_{2}, 100$ $\mathrm{mM} \mathrm{KCl}, 1 \mathrm{mM}$ DTT, $40 \mathrm{U}$ RNAsin, $200 \mu \mathrm{M}$ each of ATP, CTP, and $\mathrm{GTP}$, and $200 \mu \mathrm{Ci} \mathrm{UTP}$ for $30 \mathrm{~min}$ at $26^{\circ} \mathrm{C}$. Under these conditions, the rate of transcription is linear, as determined by parallel hybridizations with fivefold dilutions of RNA probe (data not shown). Nascent labeled RNA was isolated by DNase digestion $\left(25 \mathrm{U}, 30 \mathrm{~min}\right.$ at $\left.37^{\circ} \mathrm{C}\right)$, proteinase $\mathrm{K}$ digestion $(200 \mu \mathrm{g} / \mathrm{ml})$ in $0.5 \%$ SDS for $60 \mathrm{~min}$ at $37^{\circ} \mathrm{C}$, followed by hot phenol/chloroform extraction and repeated ethanol precipitation in $2.5 \mathrm{M}$ ammonium acetate. Target DNA filters were prepared by denaturation, neutralization, and immobilization of $10 \mu \mathrm{g}$ of linearized plasmid DNA harboring a 520-bp fragment of human VEGF165 (see above), a 400-bp fragment of the human $\beta$-actin 3' untranslated region (see above), a 1,200-bp fragment of the ROI-inducible c-myc served as a positive control to ROI, and a 2,960-bp fragment of pBluescript II served as a negative control. Hybridizations were performed with $2 \times 10^{7} \mathrm{cpm} / \mathrm{ml}$ of labeled RNA in $5 \times$ SSPE, $50 \%$ deionized formamide, $2.5 \times$ Denhardt's, and $0.25 \%$ SDS for $40 \mathrm{~h}$ at $42^{\circ} \mathrm{C}$. Filters were washed twice in $2 \times$ SSPE, $0.1 \%$ SDS for $1 \mathrm{~h}$ at $50^{\circ} \mathrm{C}$, rinsed, and then incubated $1 \mathrm{~h}$ in $2 \times$ SSPE with $10 \mu \mathrm{g} / \mathrm{ml}$ RNase A, followed by two washes in $2 \times$ SSPE, $0.1 \%$ SDS for $1 \mathrm{~h}$ at $65^{\circ} \mathrm{C}$. Filters were briefly dried and exposed to film with intensifying screens for $96 \mathrm{~h}$ at $-80^{\circ} \mathrm{C}$. Results described are representative of five experiments in which time points ranging from $40 \mathrm{~min}$ to $15 \mathrm{~h}$ were examined. Densitometry was normalized to pBluescript II signal, followed by $\beta$-actin signal.

Cycloheximide protein synthesis inhibition. Cycloheximide $(100 \mu \mathrm{M})$ was added to RPE cells $60 \mathrm{~min}$ before exposure to superoxide (X, $500 \mu \mathrm{M}$; XO, $20 \mathrm{mU} / \mathrm{ml})$ or $\mathrm{H}_{2} \mathrm{O}_{2}(400 \mathrm{mM})$ for 60 minutes. Total RNA was collected and processed as above.

Immunofluorometric VEGF protein assay. Conditioned media were lyophilized and reconstituted in PBS at 1/20 the original volume. VEGF levels in samples were determined as described previously (38). Briefly, rabbit polyclonal antibodies developed against recombinant human VEGF were used both as the capture and detection antibodies. Affinity-purified anti-VEGF IgGs were used to coat Maxisorp microtiter wells. Separately, another aliquot of the same affinity-puri- 
A

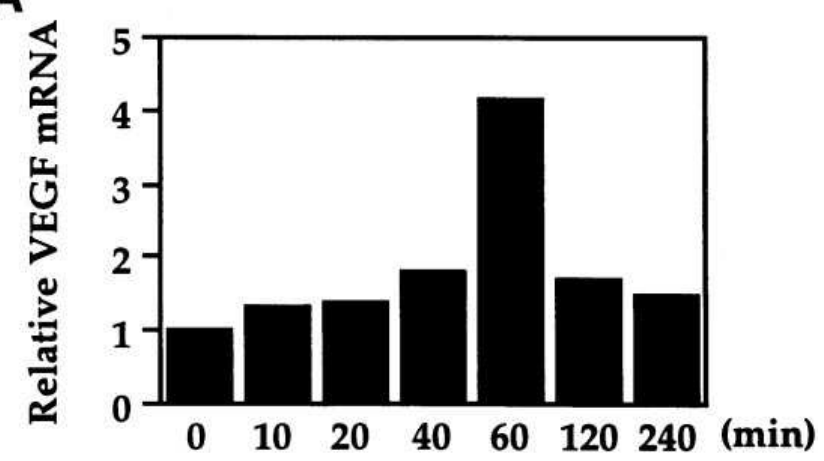

\section{VEGF}

$\beta$-actin
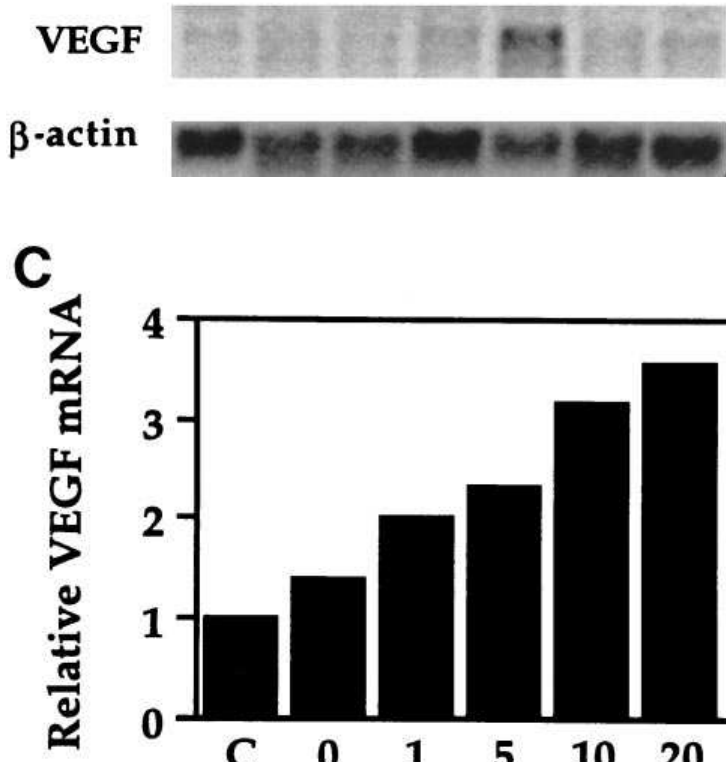

B

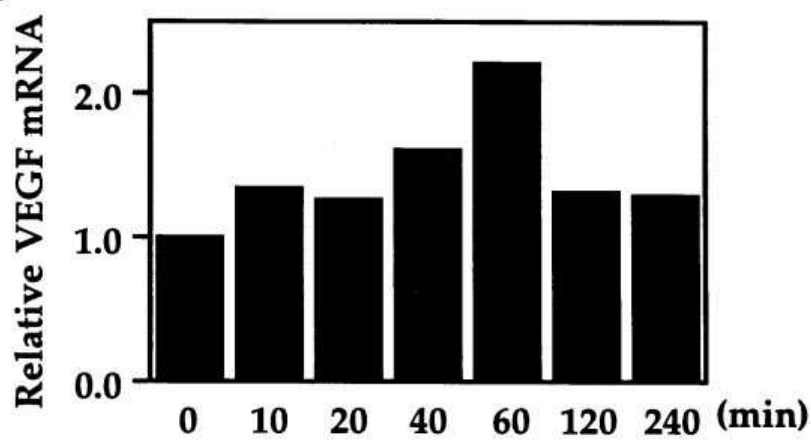

VEGF

$\beta^{-a c t i n}$
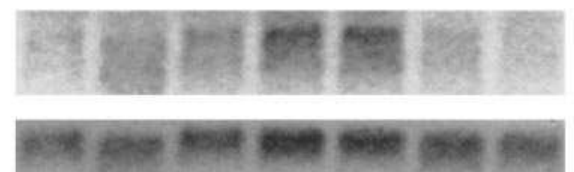

D

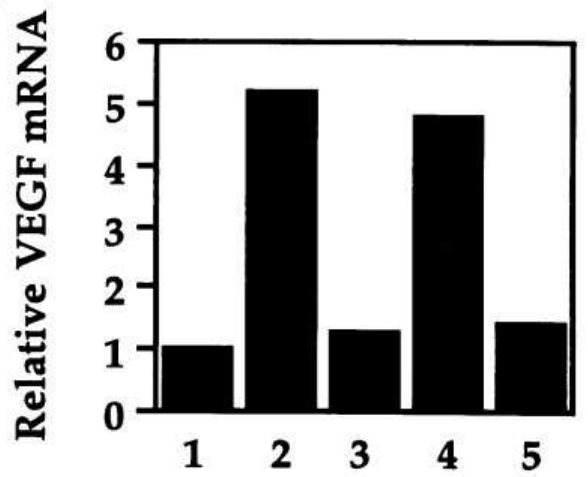

VEGF

$\beta$-actin

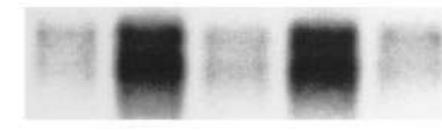

\section{$\beta$-actin}

E

2.0

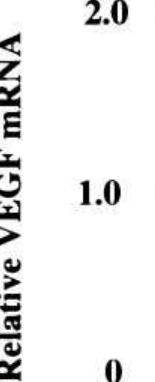

0

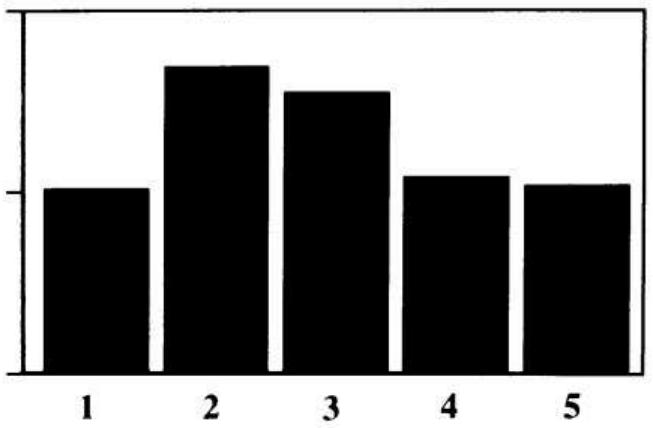

VEGF

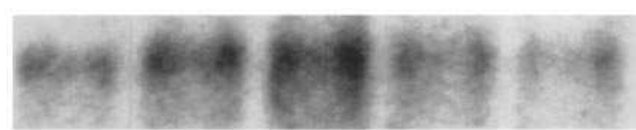

B-actin
Figure 1. Induction of VEGF mRNA by superoxide and hydrogen peroxide in human RPE cells. Time course of VEGF mRNA expression by $\mathrm{X} / \mathrm{XO}$ and $\mathrm{H}_{2} \mathrm{O}_{2}$ in RPE cells. RPE cells were treated with $\mathrm{X} / \mathrm{XO}$ (X, 500 $\mu \mathrm{M}$; XO, $20 \mathrm{mU} / \mathrm{ml})(A)$ and $\mathrm{H}_{2} \mathrm{O}_{2}(400 \mu \mathrm{M})(B)$ for the indicated times, from 0 to $240 \mathrm{~min}$ at $37^{\circ} \mathrm{C}$. Total RNA $(15 \mu \mathrm{g})$ was analyzed by Northern blot with a human VEGF cDNA probe. For comparison, the same blot was stripped and hybridized with a human $\beta$-actin probe. Dose response of RPE VEGF mRNA to superoxide $(C)$ after a 60 -min exposure to $\mathrm{X}(500 \mu \mathrm{M})$ and increasing amounts of $\mathrm{XO}$. The inhibition of superoxide- $(D)$ and hydrogen peroxide-induced $(E)$ VEGF mRNA increases. RPE cells were untreated (lane 1 ), treated with ROI (X, 500 $\mu \mathrm{M} ; \mathrm{XO}, 5 \mathrm{mU}[D]$ or $\mathrm{H}_{2} \mathrm{O}_{2} 400 \mu \mathrm{M}[E]$ ) (lane 2), ROI plus SOD (100 $\mathrm{mU}$ ) (lane 3$)$, ROI plus catalase (1,000 mU) (lane 4) or ROI plus both SOD and catalase (lane 5) for $60 \mathrm{~min}$. 
fied anti-VEGF IgGs were labeled with $\mathrm{Eu}^{3+}$-chelate (39) and used as second antibodies. In the presence of VEGF, a sandwich was formed, and after a final wash, the $\mathrm{Eu}^{3+}$ was dissociated from the second antibodies with an enhancement buffer containing $\beta$-diketone to produce a highly fluorescent chelate that was quantified in a timeresolved fluorometer. Human VEGF was used to calibrate the assay. The lower limit of detection of VEGF was $5.5 \mathrm{pM}$. Samples frozen at $-80^{\circ} \mathrm{C}$ have previously been shown to retain all of their activity. Values were normalized to cell counts.

Bovine capillary endothelial cell DNA synthesis assay. RPE cells were treated with $100 \mu \mathrm{l} \mathrm{PBS} \pm \mathrm{X} / \mathrm{XO}(\mathrm{X}, 500 \mu \mathrm{M}$; XO, $5 \mathrm{mU} / \mathrm{ml})$. Conditioned media were collected at the indicated times and incubated with heparin sepharose for $16 \mathrm{~h}$. The heparin sepharose was washed twice with $0.5 \mathrm{ml}$ of $0.5 \mathrm{M} \mathrm{NaCl}$ and eluted with $50 \mu \mathrm{l} 1.5 \mathrm{M}$ $\mathrm{NaCl}$. Bovine capillary endothelial cells were seeded in 96-well plates (400 cells/well per $200 \mu \mathrm{l}$ ) and grown in DMEM supplemented with $2 \%$ bovine calf serum. The cells were incubated in $10 \% \mathrm{CO}_{2}$ at $37^{\circ} \mathrm{C}$ for $24 \mathrm{~h}$, and $3-\mu \mathrm{l}$ samples of concentrated conditioned media were added to the cells. A previously characterized anti-VEGF monoclonal antibody $(3,5)$ was added in some wells and a previously characterized anti-gp120 monoclonal antibody $(3,5)$ was added to parallel wells as a control. After $48 \mathrm{~h}, 10 \mu \mathrm{l}(0.2 \mu \mathrm{Ci})$ of $\left[{ }^{3} \mathrm{H}\right]$ thymidine (specific activity $27 \mathrm{mCi} / \mathrm{mg}$ ) was added for $6 \mathrm{~h}$ and $\left[{ }^{3} \mathrm{H}\right]$ thymidine incorporation into DNA was determined by liquid scintillation counting. Values were normalized to cell number.
In vivo retinal ischemia and reperfusion. The rabbit experiments were approved by the Animal Care Committee of the Massachusetts Eye and Ear Infirmary and conform with the current Association for Research in Vision and Ophthalmology guidelines for animal experimentation. New Zealand albino rabbits weighing $1.2-1.8 \mathrm{~kg}$, were anesthetized with an intramuscular injection of $50 \mathrm{mg} / \mathrm{kg}$ ketamine and $10 \mathrm{mg} / \mathrm{kg}$ xylazine. Two methods were used to generate retinal ischemia and reperfusion in vivo $(40,41)$. A 22 -gauge cannula attached to 1 liter of normal saline was passed through the limbus and the tip placed between the lens and cornea. The saline bag was elevated $2 \mathrm{~m}$ above eye level to produce an intraocular pressure of $150 \mathrm{mmHg}$ with complete occlusion of retinal vessels. At the end of the ischemic period, the bag was lowered to eye level to allow reperfusion (40). Control eyes were cannulated and the IV bags kept at eye level. For the second method, the eye was gently proptosed and ischemia was produced with a 6-0 silk suture tied around the ophthalmic artery and posterior ciliary arteries (41). Reperfusion was achieved with release of the suture. Occlusion and reperfusion were monitored by direct ophthalmoscopy for both methods. $100 \mu \mathrm{g} / \mathrm{ml} \mathrm{SOD}, 1,500 \mathrm{U} / \mathrm{ml}$ catalase, $10 \mathrm{mM}$ DMTU, or $900 \mathrm{mg} / \mathrm{ml}$ allopurinol in a total volume of $100 \mu \mathrm{l}$ PBS were injected intravitreally either individually or in combination 20 min before reperfusion with a 27-gauge needle attached to a 1-ml syringe. The needle was passed through the pars plana and into the center of the vitreous. Contralateral control eyes received $100-\mu l$ injections of PBS alone. At the end of the experiment, the eyes

A

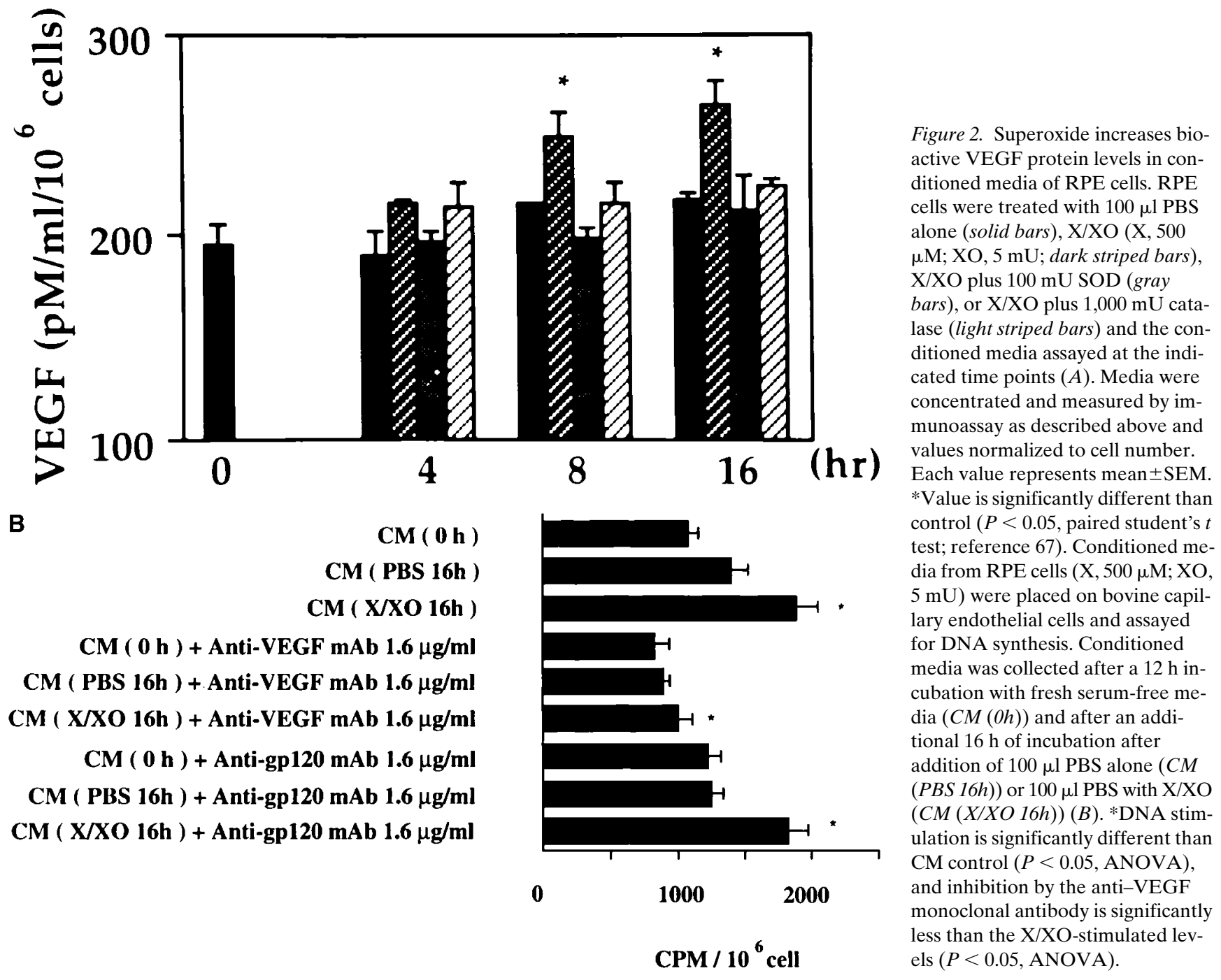




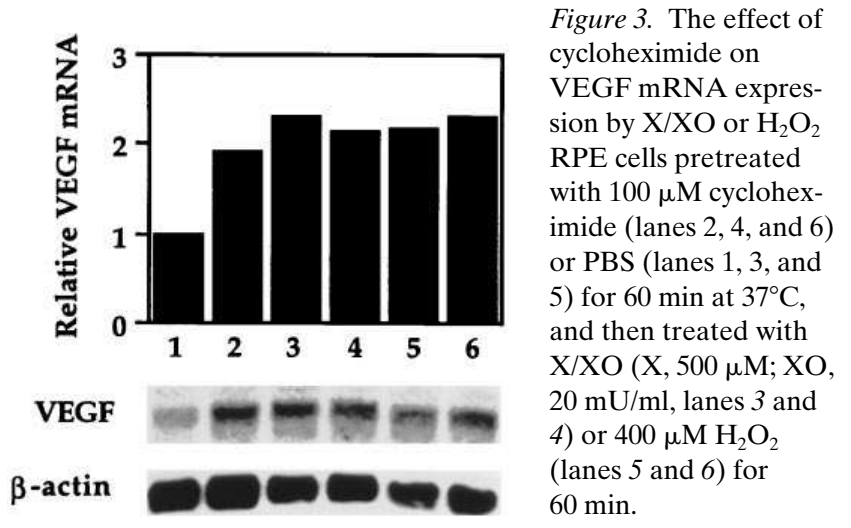

were enucleated and bisected at the equator. The retina was gently dissected and cut free at the disc. The tissue was placed in a 50-ml plastic tube, immediately frozen in liquid nitrogen and stored at $-80^{\circ} \mathrm{C}$ until preparation for Northern blotting. The animals were killed with $50 \mathrm{mg} / \mathrm{kg}$ intravenous pentobarbital. The retinas were homogenized in $2 \mathrm{ml} \mathrm{RNAzol}\left(25^{\circ} \mathrm{C}\right)$ and prepared for Northern blotting as described above. The results described are representative of three separate experiments.

\section{Results}

The steady state production of superoxide by xanthine and xanthine oxidase (X, $500 \mu \mathrm{M}$; XO, $20 \mathrm{mU} / \mathrm{ml}$ ) (Fig. $1 A$ ), or the addition of hydrogen peroxide $(400 \mu \mathrm{M})($ Fig. $1 B)$ rapidly increased VEGF levels in cultured human RPE cells by $40-60$ min. A dose response to superoxide was evident with increas- ing XO concentrations (Fig. $1 C$ ). Coincubation of superoxidetreated cells $(\mathrm{X}, 500 \mu \mathrm{M}$; XO, $5 \mathrm{mU} / \mathrm{ml})$ with $100 \mathrm{U} / \mathrm{ml}$ of superoxide dismutase, but not 1,000 U/ml catalase, prevented the ROI-associated increases in VEGF mRNA (Fig. $1 \mathrm{D}$ ). The combination of catalase and superoxide dismutase suppressed the increases in VEGF expression as well as superoxide dismutase alone. Similarly, coincubation of hydrogen peroxidetreated cells $(400 \mu \mathrm{M})$ with catalase $(1,000 \mathrm{U} / \mathrm{ml})$, but not superoxide dismutase $(100 \mathrm{U} / \mathrm{ml})$, blocked the increases in VEGF expression (Fig. $1 E$ ). Superoxide and hydrogen peroxide also increased VEGF mRNA levels in human MMAN melanoma and rat C6 glioblastoma cells (data not shown). The increases were delayed, but were larger and more sustained than in the RPE cells. Both the melanoma and glioblastoma cells were more sensitive to superoxide and $\mathrm{H}_{2} \mathrm{O}_{2}$ than the RPE cells (data not shown), requiring lower concentrations of each ROI to produce the increased VEGF mRNA levels (X, $\left.500 \mu \mathrm{M} ; \mathrm{XO}, 5 \mathrm{mU} / \mathrm{ml} ; \mathrm{H}_{2} \mathrm{O}_{2}, 200 \mathrm{mM}\right)$. Concentrations of ROI similar to those used for the RPE cells resulted in cell death for both the MMAN melanoma and the C6 glioblastoma cells (data not shown). The blots were stripped and examined with a human $\beta$-actin probe and showed no change with ROI treatment in all of the above experiments (Fig. 1, $A-E$ ).

The ROI-associated VEGF mRNA increases were translated into bioactive VEGF protein. Conditioned media were collected from superoxide-treated (X, $500 \mu \mathrm{M} ; \mathrm{XO}, 20 \mathrm{mU} / \mathrm{ml}$ ) and vehicle-treated RPE cells at various time points and the VEGF levels quantified by immunoassay. Superoxide-treated cells significantly increased secreted VEGF levels compared with controls (Fig. $2 \mathrm{~A}$ ). Coincubation of superoxide-treated cells $(\mathrm{X}, 500 \mu \mathrm{M} ; \mathrm{XO}, 5 \mathrm{mU} / \mathrm{ml})$ with $100 \mathrm{U} / \mathrm{ml}$ of superoxide dismutase $\pm 1,000 \mathrm{U} / \mathrm{ml}$ catalase prevented the ROI-associated
A
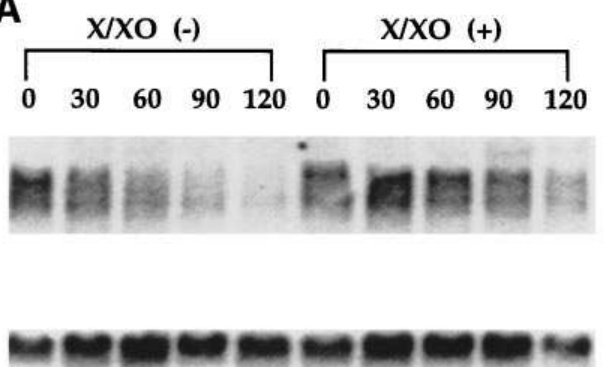

c

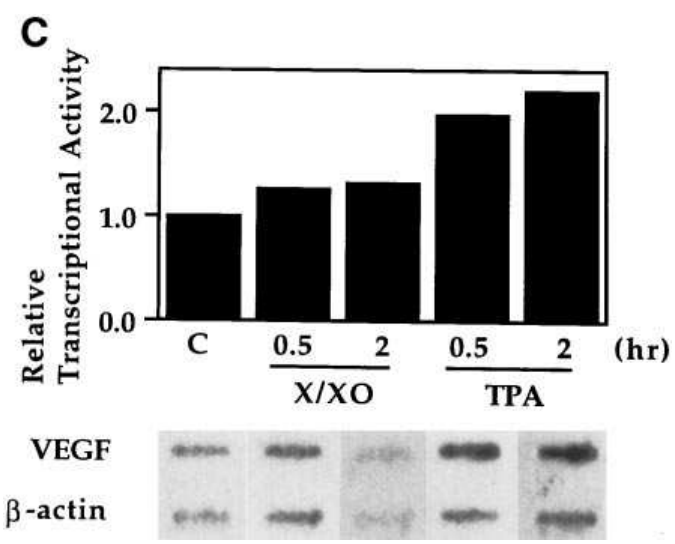

$18 \mathrm{~S}$

$(\min )$

$28 \mathrm{~S}$

$\beta$-actin

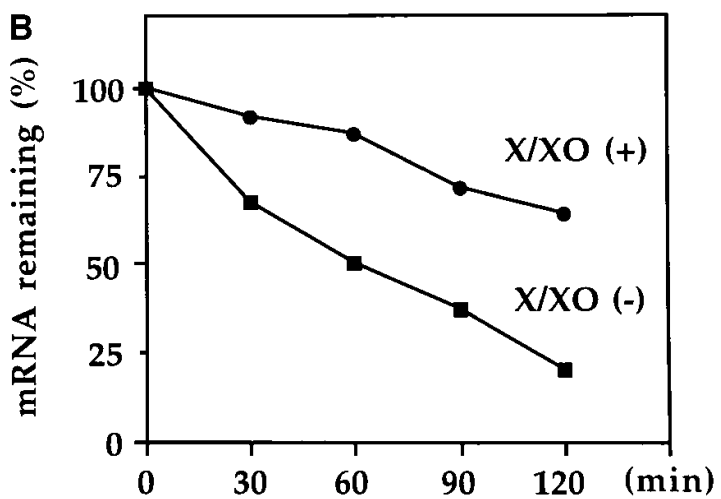

Figure 4. (A) The effect of ActD on VEGF mRNA expression by X/XO in RPE cells. RPE cells were treated with $\mathrm{X} / \mathrm{XO}(\mathrm{X}, 500 \mu \mathrm{M} ; \mathrm{XO}, 20 \mathrm{mU} / \mathrm{ml})$ in the presence of ActD $(5 \mu \mathrm{g} / \mathrm{ml})$ for $60 \mathrm{~min}$ after pretreatment with ActD $(5 \mu \mathrm{g} / \mathrm{ml})$ for $60 \mathrm{~min}$ at $37^{\circ} \mathrm{C}$. Total RNA $(15 \mu \mathrm{g})$ was analyzed by Northern blotting with human VEGF cDNA probe. The locations of $28 \mathrm{~S}$ and $18 \mathrm{~S}$ rRNAs are indicated by arrowheads. For comparison, the same blot was stripped and hybridized with $\beta$-actin probe. $(B)$ Graph of decay of transcript signal over time normalized to $\beta$-actin transcript signal. $(C)$ The effect of ROI and TPA on VEGF transcriptional activation. Nuclear run-on analyses were performed at 30 and $120 \mathrm{~min}$ after exposure to X/XO. Densitometry of VEGF normalized run-on analysis. 
increases in VEGF-secreted protein. Catalase alone, at the concentration used, did not inhibit the ROI-induced increases. To determine if the ROI-associated VEGF protein increases are functionally relevant, the conditioned media of ROItreated RPE cells were tested for their ability to stimulate capillary endothelial cell DNA synthesis. Superoxide-treated RPE cell-conditioned media significantly increased capillary endothelial cell DNA synthesis and the increases were blocked with an anti-VEGF-neutralizing monoclonal antibody (Fig. 2 B).

To further delineate the mechanism of the ROI-associated VEGF increases, protein synthesis and transcription were inhibited and nuclear run-on assays were performed. Cycloheximide alone potentiated VEGF mRNA levels when added to RPE cells, as previously described (22). Incubation of cycloheximide-treated cells with superoxide or $\mathrm{H}_{2} \mathrm{O}_{2}$ did not increase the VEGF mRNA levels beyond those observed with cycloheximide alone (Fig. 3).

The effect of superoxide on the stability of VEGF mRNA was examined. A preliminary control $\left[\mathrm{H}^{3}\right] \mathrm{UTP}$-incorporation study demonstrated that pretreatment with $5 \mu \mathrm{g} / \mathrm{ml}$ actinomycin D for 60 min inhibited RNA synthesis by $94 \%$ (data not shown). Treatment with Actinomycin D for 60 min followed by treatment \pm superoxide resulted in an increase in VEGF mRNA half-life in the ROI-treated cells $\left(t_{1 / 2}>120\right.$ vs $\left.60 \mathrm{~min}\right)$ (Fig. 4, $A$ and $B$ ). The half-life of the VEGF mRNA in the non-ROI-treated cells is consistent with previous reports (36).

Nuclear run-on experiments were performed to assess the effect of ROI on VEGF mRNA transcription (Fig. 4 C). Exposure of RPE cells to superoxide for 30 and 120 min showed no increase in mRNA transcriptional activation. TPA stimulated VEGF transcription, as previously described (36). ROI-induced c-myc transcription served as a positive control (data not shown) (42). Five separate experiments failed to show an increase in VEGF transcriptional rate to superoxide.

The effect of reoxygenation on VEGF steady state mRNA and protein levels was studied. $12 \mathrm{~h}$ after changing to serumfree media, RPE cells were exposed to continuous hypoxia for $16 \mathrm{~h}$ and then returned to normoxia. Total RNA and conditioned media were isolated and analyzed for VEGF mRNA and protein levels at different time points after reoxygenation. Hypoxia alone increased the steady state VEGF mRNA levels in RPE cells after $16 \mathrm{~h}$ (Fig. $5 \mathrm{~A}$ ), as previously described (43). Reoxygenation produced an additional increase, with peak mRNA levels occurring 40-60 min after exposure to normoxia, paralleling the time course observed after exposure to exogenous ROI. Steady state protein levels after reoxygenation were also increased after reoxygenation (Fig. 5 B). Parallel normoxic wells showed no change in VEGF steady state conditioned media levels at the 0 - and 8-h time points (data not shown).

Reperfusion of ischemic retinal tissue increased VEGF mRNA levels in vivo. Both methods for producing ischemia and reperfusion yielded the same results (Fig. $6 \mathrm{~A}$ ). $60 \mathrm{~min}$ of pressure-induced ischemia followed by reperfusion resulted in an increase in VEGF mRNA at 40, but not at 10 or $120 \mathrm{~min}$ of reperfusion (Fig. $6 \mathrm{~B}$ ). The time course and degree of upregulation paralleled the exogenous ROI and reoxygenation responses in vitro. Intravitreal injections of DMTU, allopurinol, and catalase alone or in combination prevented the VEGF mRNA increases after reperfusion Superoxide dismutase had no effect at the dose tested. (Fig. $6 C$ ).

\section{Discussion}

ROI such as superoxide and hydrogen peroxide are ubiquitous in living cells and tissues. At least four separate biochemical pathways contribute to their generation: (a) xanthine/xanthine oxidase (44), (b) NADPH oxidase (45), (c) mitochondrial electron transport (46), and $(d)$ the arachidonate pathway (47). Relatively large concentrations of ROI can be generated after reoxygenation in vitro and reperfusion of ischemic tissue in vivo. ROI generation can also occur in response to inflammatory cytokines (48), and some tissues (e.g., tumors) have constitutively elevated ROI levels (34) via mechanisms that are not fully characterized.

ROI levels are tightly controlled in cells and tissues, partly through the action of multiple intracellular and extracellular antioxidants. The antioxidants, in turn, are themselves tightly

\section{A}
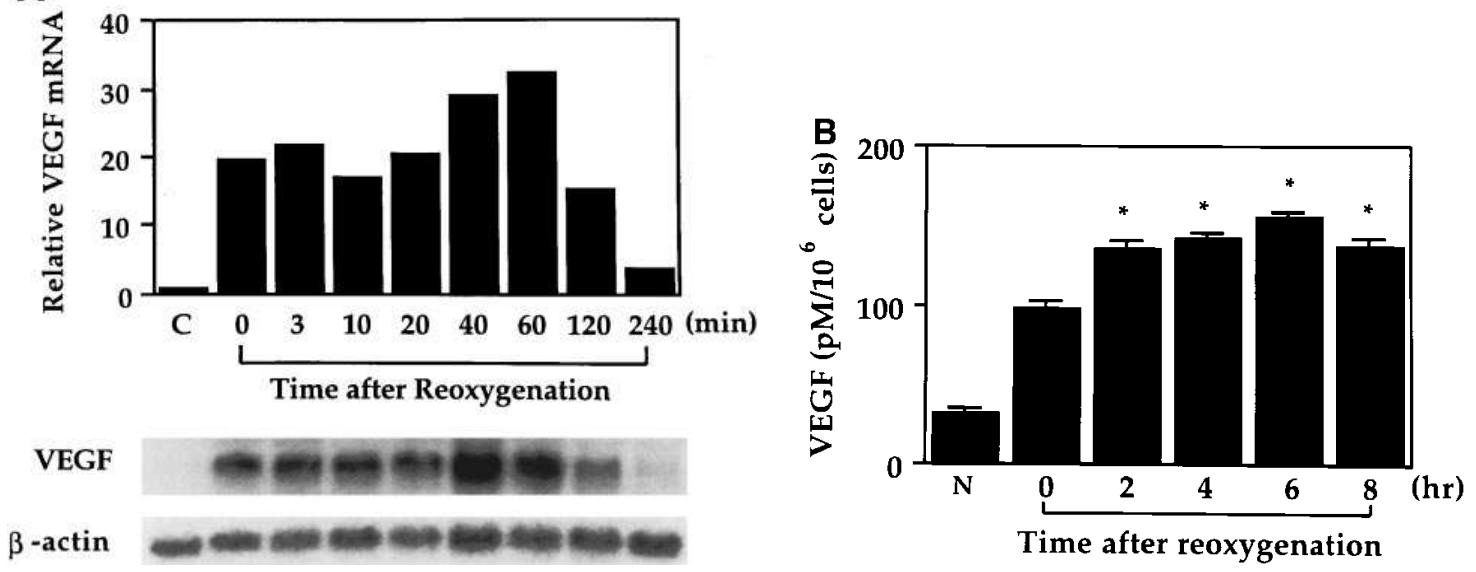

Figure 5. The effect of reoxygenation on VEGF mRNA expression in RPE cells. ( $A$ ) RPE cells were exposed to hypoxia for $16 \mathrm{~h}$, followed by normoxia for the indicated times. Total RNA $(15 \mu \mathrm{g})$ was analyzed by Northern blotting with a human VEGF cDNA probe. C $=$ normoxia. For comparison, the same blot was stripped and hybridized with a $\beta$-actin probe. (B) Conditioned media protein levels vs time of RPE exposed to $16 \mathrm{~h}$ of hypoxia, followed by reoxygenation for the indicated times. $\mathrm{N}=$ normoxia. *Value is significantly different from the zero time point $(P<$ 0.05 , paired student's $t$-test; reference 67 ). 
A

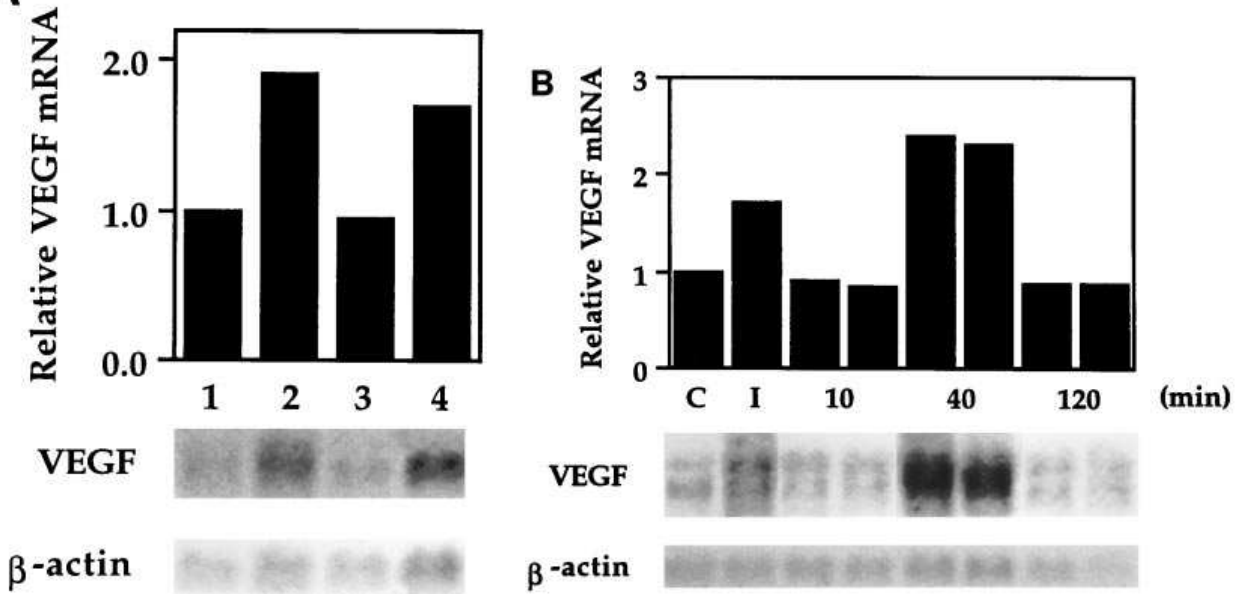

Figure 6. Response of rabbit retina to reperfusion. $(A)$ VEGF northern blot of total retinal RNA showing comparison between the intraocular pressure and vessel ligation methods of ischemia reperfusion. Control eye with normal perfusion (i.e., no ischemia or reperfusion) (lane 1 ), contralateral eye with $60 \mathrm{~min}$ of ischemia

C

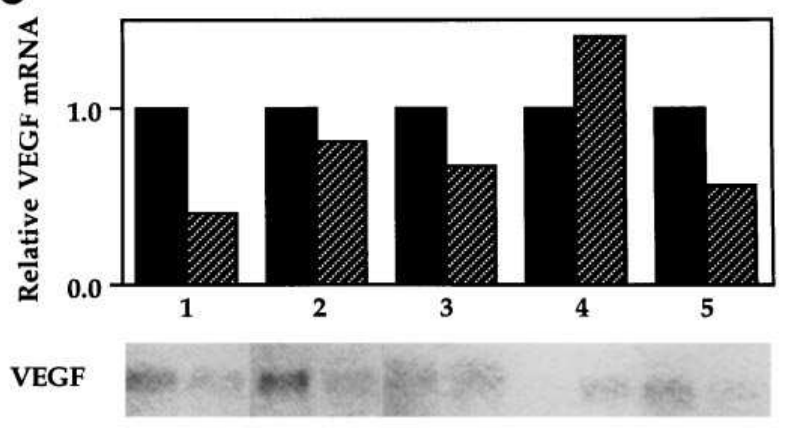

$\beta$-actin through increased intraocular pressure, followed by $40 \mathrm{~min}$ of reperfusion (lane 2), $100 \mathrm{~min}$ of ischemia alone via ligation (lane 3), and contralateral eye with $40 \mathrm{~min}$ reperfusion after $60 \mathrm{~min}$ of ischemia via ligation (lane 4). (B) VEGF northern blot of total retinal RNA of a normal eye (lane $C$ ) and contralateral eye after $60 \mathrm{~min}$ of ischemia (lane 1), two eyes of the same animal with $60 \mathrm{~min}$ of ischemia and $10 \mathrm{~min}$ of reperfusion (lanes 3 and 4), two eyes of the same animal after $60 \mathrm{~min}$ of ischemia and $40 \mathrm{~min}$ of reperfusion (lanes 5 and 6), and two eyes of the same animal with 60 and 120 min of reperfusion (lanes 7 and 8), using the intraocular pressure method. (C) VEGF northern blot of total retinal RNA showing an increase in VEGF mRNA after $40 \mathrm{~min}$ of reperfusion and injection of $100 \mu \mathrm{l}$ PBS using the ligation method (black bars) and its inhibition with a $100-\mu l$ injection of antioxidants in the contralateral eye (striped bars). Treatment with $10 \mathrm{mM}$ DMTU (animal 1), 90 $\mathrm{mg} / \mathrm{ml}$ allopurinol (animal 2), 1,500 U/ml catalase (animal 3), $100 \mathrm{mg} / \mathrm{ml}$ SOD (animal 4), and a combination of allopurinol, catalase, and SOD (animal 5). Volume of rabbit eye $=1.5 \mathrm{ml}$. regulated $(49,50)$. This level of control is probably necessary because ROI exert multiple and varied biological actions. In large concentrations, ROI are toxic to cells. However, in lower concentrations, ROI can mobilize intracellular ions and alter $\mathrm{pH}(51,52)$, induce c-fos, c-jun, and c-myc protooncogene transcription and cell proliferation $(42,53,54)$, and serve as intracellular second messengers (55-57).

We examined the role of ROI in VEGF gene expression because of their association with ischemic hypoxia and angiogenesis. Our data indicate that ROI increase VEGF gene expression in vitro and in vivo. Human retinal pigment epithelial cells, human MMAN melanoma, and rat C6 glioblastoma cells each increased VEGF mRNA levels in response to either exogenous superoxide or hydrogen peroxide. The increases were specific and dose dependent.

Human RPE increased VEGF mRNA levels transiently to both superoxide and $\mathrm{H}_{2} \mathrm{O}_{2}$. The ROI-associated increases in MMAN melanoma and rat C6 glioblastoma cells were more pronounced and sustained than those observed in the RPE cells (data not shown). The mechanisms underlying these differing responses are not known. We speculate that the ability of the RPE to rapidly change its constitutively high antioxidant levels in response to environmental stimuli may account for the observed difference (50, 58). The results, however, underscore the variability of the magnitude and duration of the response in different cell types.

Reoxygenation of the RPE cells after $16 \mathrm{~h}$ of hypoxia increased steady state VEGF mRNA levels above those seen with hypoxia alone. The increases occurred 40-60 min after re- oxygenation, with levels rapidly decreasing thereafter. The increased VEGF mRNA levels corresponded in timing and degree to the response elicited by exogenous ROI on RPE cells, indirectly supporting the identification of ROI as the inducers of the reoxygenation response.

Conditioned media measurements confirmed that the ROIassociated mRNA increases were translated into protein when ROI were added directly to cells or when ROI were generated after the reoxygenation of hypoxic cells. Further, the increases in conditioned media VEGF were able to stimulate DNA synthesis in capillary endothelial cells, a critical step in angiogenesis (Fig. 2 B). Persistently elevated VEGF protein levels were observed in the conditioned media and most likely reflected the relative stability of the protein compared to the mRNA. As others have shown, the detection of VEGF in the conditioned media is consistent with the presence of the 121 and/or 165 amino acid isoforms of VEGF, isoforms with little or no heparin affinity (12).

To confirm the relevance of the ROI-mediated VEGF response in vivo, retinal reperfusion experiments were performed (Fig. 6, $A-C$ ). Ischemia was induced with increased intraocular pressure followed by reperfusion. Retinal VEGF mRNA levels were increased after $40 \mathrm{~min}$ of reperfusion (Fig. 6 A). To control for the confounding variable of elevated intraocular pressure, the vessel ligation method for inducing retinal ischemia was also examined and demonstrated a similar increase in VEGF mRNA levels. Reperfusion of ischemic retina resulted in a peak of VEGF mRNA levels at 40, but not at 
20 or 120 min (Fig. 6 B). This was followed by a rapid normalization of mRNA levels (a time course similar to both the exogenous ROI and reoxygenation experiments in vitro). Smaller increases in VEGF mRNA were observed after $60 \mathrm{~min}$ of ischemia alone, a short time period for very large increases in VEGF mRNA secondary to hypoxia (59). Inhibition of the reperfusion-associated VEGF mRNA increases with the antioxidants DMTU, superoxide dismutase, and allopurinol confirmed that ROI serve as the mediators of the reperfusion-associated VEGF mRNA increases. The efficacy of the individual antioxidants differed in vivo and in vitro. We speculate that multiple different ROI species were generated in vivo after reperfusion, since all cell layers of the retina, including the RPE, were ischemic. Further, the activity of each antioxidant is dose- and ROI-dependent, as well as a function of its intracellular access. Some or all of these variables likely differed between the in vitro and in vivo conditions.

ROI increased VEGF mRNA levels transiently in the RPE in vitro and in the retina in vivo; however, brief exposures to VEGF can produce significant biological effects. Roberts and Palade (60) placed exogenous VEGF directly on blood vessels and documented increased permeability within $10 \mathrm{~min}$. Ultrastructural analysis demonstrated the acquisition of a fenestrated phenotype by the endothelial cells. Of note, ROI scavengers prevent increased intestinal vascular permeability after reperfusion and inflammation-induced edema $(61,62)$. It is conceivable that ROI-associated VEGF, in addition to direct ROI-associated endothelial damage, contributes to the increased vascular permeability associated with reperfusion events.

The ROI-associated increases in VEGF mRNA were not observed after treatment with cycloheximide. Although cycloheximide alone increased VEGF levels, it prevented the inducible stabilization of VEGF mRNA secondary to ROI. The dependence of the ROI-induced increase on protein synthesis suggests another more proximal event before the stabilization of VEGF mRNA.

The actinomycin D experiments with the RPE and C6 glioblastoma cells demonstrated that the increases in VEGF mRNA levels occur, in part, through an increase in VEGF mRNA half-life. The finding that superoxide can inducibly increase the half-life of a transcript identifies a new activity for this molecular species. These data complement the nuclear run-on results showing a lack of VEGF transcriptional activation by ROI.

Like ROI, hypoxia-associated increases in VEGF mRNA levels involve transcript stabilization $(36,63,64)$ and are protein synthesis dependent (23). Since the data presented herein demonstrate a similar mode of regulation, it is conceivable that ROI serve as mediators of the hypoxia-associated VEGF increases. Electron spin resonance spectroscopy has demonstrated elevated ROI levels in hypoxic mouse brains in vivo (65). The recent finding that the ROI-generating NADPH oxidase acts as a hypoxia sensor for other cell types is also consistent with this hypothesis (66).

In summary, our studies demonstrate that ROI increase VEGF gene expression in vitro and in vivo. Thus, ROI may serve as indirect angiogenic and vascular permeability factors through their actions on VEGF gene expression in vivo.

\section{Acknowledgments}

Human VEGF cDNA was the kind gift of Dr. Herbert Weich, Albert-Ludwigs Universitat, Freiburg, Germany. Mouse VEGF cDNA was the kind gift of Georg Breier, Max Planck Institute, Bad Nauheim, Germany. Anti-VEGF and anti-gp120 antibodies were the kind gift of Dr. Napoleone Ferrara, Genentech, Inc. (South San Francisco, CA). The authors thank Drs. Frederick A. Jakobiec and Judah Folkman for their continued support, Dr. David T. Shima for his advice and comments, and Ying Zhou for her technical expertise.

E.E. Voest is a fellow of the Dutch Cancer Society. A.P. Adamis is a Research to Prevent Blindness Robert E. McCormick Scholar. This work was funded by the Jichi Medical School (M. Kuroki), National Eye Institute (A.P. Adamis), Massachusetts Lions Eye Research Fund (A.P. Adamis) and the Knights Templar Eye Foundation (A.P. Adamis).

\section{References}

1. Senger, D.R., S.J. Galli, A.M. Dvorak, C.A. Perruzzi, V.S. Harvey, and H.F. Dvorak. 1983. Tumor cells secrete a vascular permeability factor that promotes accumulation of ascites fluid. Science (Wash. DC). 219:983-985.

2. Millauer, B., L.K. Shawver, K.H. Plate, W. Risau, and A. Ullrich. 1994. Glioblastoma growth inhibited in vivo by a dominant-negative Flk-1 mutant. Nature (Lond.). 367:576-579.

3. Kim, K.J., B. Li, J. Winer, M. Armanini, N. Gillett, H.S. Phillips, and N. Ferrara. 1993. Inhibition of vascular endothelial growth factor-induced angiogenesis suppresses tumour growth in vivo. Nature (Lond.). 362:841-844.

4. Miller, J.W., A.P. Adamis, D.T. Shima, P.A. D'Amore, R.S. Moulton, M.S. O'Reilly, J. Folkman, H.F. Dvorak, L.F. Brown, B. Berse et al. 1994. Vascular endothelial growth factor/vascular permeability factor is temporally and spatially correlated with ocular angiogenesis in a primate model. Am. J. Pathol. 145:574-584.

5. Adamis, A.P., D.T. Shima, M. Tolentino, E.S. Gragoudas, N. Ferrara, J. Folkman, P.A. D'Amore, and J.W. Miller. 1996. Inhibition of vascular endothelial growth factor prevents retinal ischemia-associated iris neovascularization in a non-human primate. Arch. Ophthalmol. 114:66-71.

6. Tolentino, M.T., J.W. Miller, E.S. Gragoudas, K. Chatzistefanou, N. Ferrara, and A.P. Adamis. 1996. Vascular endothelial growth factor is sufficient to produce iris neovascularization and neovascular glaucoma in a non-human primate. Arch. Ophthalmol. 114:964-970.

7. Tolentino, M.J., J.W. Miller, E.S. Gragoudas, F.A. Jakobiec, E. Flynn, K Chatzistefanou, N. Ferrara, and A.P. Adamis. 1996. Intravitreal injections of vascular endothelial growth factor produce retinal ischemia and microangiopathy in an adult primate. Ophthalmology. In press.

8. Adamis, A.P., J. Miller, M. Bernal, D.J. D'Amico, J. Folkman, T. Yeo, and K. Yeo. 1994. Increased vascular endothelial growth factor levels in the vitreous of eyes with proliferative diabetic retinopathy. Am. J. Ophthalmol. 118: $445-450$.

9. Aiello, L.P., R.L. Avery, P.G. Arrigg, B.A. Keyt, H.D. Jampel, S.T. Shah, L.R. Pasquale, H. Thieme, M.A. Iwamoto, J.E. Park et al. 1994. Vascular endothelial growth factor in ocular fluid of patients wth diabetic retinopathy and other retinal disorders. N. Engl. J. Med. 331:1480-1487.

10. Malecaze, F., S. Clamens, V. Simorre-Pinatel, P. Chollet, C. Favard, F. Bayard, and J. Plouet. 1994. Detection of vascular endothelial growth factor messanger RNA and vascular endothelial growth factor-like activity in proliferative diabetic retinopathy. Arch. Ophthalmol. 112:1476-1482.

11. Aiello, L.P., E.A. Pierce, E.D. Foley, H. Takagi, H. Chen, L. Riddle, N. Ferrara, G. King, and L.E.H. Smith. 1995. Suppression of retinal neovascularization in vivo by inhibition of vascular endothelial growth factor (VEGF) using soluble VEGF-receptor chimeric proteins. Proc. Nat. Acad. Sci. USA. 92: 10457-10461.

12. Ferrara, N., K.A. Houck, J. Jakeman, J. Winer, and D.W. Leung. 1991 The vascular endothelial growth factor family of polypeptides. J. Cell. Biochem. 47:211-218

13. Shima, D.T., M. Kuroki, U. Deutsch, Y. Ng, A.P. Adamis, and P.A. D'Amore. 1996. The mouse gene for vascular endothelial growth factor. Genomic structure, definition of the transcriptional unit, and characterization of the transcriptional and post-transcriptional regulatory sequences. J. Biol. Chem. 271:3877-3883.

14. Leung, D.W., G. Cachianes, W.J. Knang, D.W. Goeddel, and N. Ferrara. 1989. Vascular endothelial growth factor is a secreted angiogenic mitogen. Science (Wash. DC). 246:1206-1309.

15. Senger, D.R., L. van de Water, L.F. Brown, J.A. Nagy, K.T. Yeo, T.K Yeo, B. Berse, R.W. Jackman, A.M. Dvorak, and H.F. Dvorak. 1993. Vascular permeability factor (VPF, VEGF) in tumor biology. Cancer Metastasis Reviews. 12:303-324.

16. Houck, K.A., D.W. Leung, A.M. Rowland, J. Winer, and N. Ferrara. 1992. Dual regulation of vascular endothelial growth factor bioavailability by genetic and proteolytic mechanisms. J. Biol. Chem. 267:26031-26037.

17. Goldman, C.K., J. Kim, W. Wong, V. King, T. Brock, and G.Y. Gillespie. 1993. Epidermal growth factor stimulates vascular endothelial growth factor production by human malignant glioma cells: a model of glioblastoma 
multiforme pathophysiology. Mol. Biol. Cell. 4:121-133.

18. Goldberg, M.A., and T.J. Schneider. 1994. Similarities between the oxygen-sensing mechanisms regulating the expression of vascular endothelial growth factor and erythropoietin, J. Biol. Chem. 269:4335-4359.

19. Garrido, C., S. Saule, and D. Gospodarowicz. 1993. Transcriptional regulation of vascular endothelial growth factor gene expression in ovarian bovine granulosa cells. Growth Factors. 8:109-117.

20. Harada, S., J.A. Nagy, K.A. Sullivan, K.A. Thomas, N. Endo, G.A. Rodan, and S.B. Rodan. 1994. Induction of vascular endothelial growth factor expression by prostaglandin E1 and E2 in osteoblasts. J. Clin. Invest. 93:2490-2493.

21. Cullinan-Bove, K., and R.D. Koos. 1993. Vascular endothelial growth factor/vascular permeability factor expression in the rat uterus: rapid stimulation by estrogen correlates with estrogen-induced increases in uterine capillary permeability and growth. Endocrinology. 133:829-837.

22. Shweiki, D., A. Itin, D. Soffer, and E. Keshet. 1992. Vascular endothelial growth factor induced by hypoxia may mediate hypoxia-initiated angiogenesis. Nature (Lond.). 359:843-845.

23. Plate, K.H., G. Breier, H.A. Weich, and W. Risau. 1992. Vascular endothelial growth factor in human glioblastoma in vivo. Nature (Lond.). 358: 845-848.

24. Schroder, S., W. Palinski, and G.W. Schmid-Schonbein. 1991. Activated monocytes and granulocytes, capillary nonperfusion, and neovascularization in diabetic retinopathy. Am. J. Pathol. 139:81-100.

25. Yamana, Y., Y. Oka, Y. Ohnishi, T. Ishibashi, and T. Inoguchi. 1988. Reflow of obstructed capillaries in the maculae of humans with diabetic retinopathy observed by fluorescein angiography. Br. J. Ophthalmol. 72:660-665.

26. Augustin, A.J., W. Breipohl, T. Boker, J. Lutz, and M. Spitznas. 1993. Increased lipid peroxide levels and myeloperoxidase activity in the vitreous of patients suffering from proliferative diabetic retinopathy. Grafe's Arch. Clin. Exp. Ophthalmol. 231:647-650.

27. Armstrong, D., and F. al-Awadi. 1991. Lipid peroxidation and retinopathy in streptozotocin-induced diabetes. Free Rad. Biol. Med. 11:433-436.

28. Saugstad, O.D., and T.O. Rognum. 1988. High postmortem levels of hypoxanthine in the vitreous humor of premature babies with respiratory distress syndrome. Pediatrics. 81:395-398.

29. Stone, J., T. Chan-Ling, J. Pe'er, A. Itin, H. Gnessin, and E. Keshet. 1996. Roles of vascular endothelial growth factor and astrocyte degeneration in the genesis of retinopathy of prematurity. Invest. Ophthalmol. Visual Sci. 37: 290-299.

30. Pierce, E.A., R.L. Avery, E.D. Foley, L.P. Aiello, and L.E.H. Smith. 1995. Vascular endothelial growth factor/vascular permeability factor expression in a mouse model of retinal neovascularization. Proc. Natl. Acad. Sci. USA. 92:905-909.

31. Pe'er, J., D. Shweiki, A. Itin, I. Hemo, H. Gnessin, and E. Keshtet. 1995. Hypoxia-induced expression of vascular endothelial growth factor by retinal cells is a common factor in neovascularizing ocular diseases. Lab. Invest. 72:638-645.

32. Jain, R.K. 1988. Determinants of tumor blood flow: a review. Cancer Res. 48:2641-2658

33. Monte, M., L.E. Davel, and E.S. deLustig. 1994. Inhibition of lymphocyteinduced angiogenesis by free radical scavengers. Free Rad. Biol. Med. 17:259-266.

34. Voest, E.E., E. van Faassen, B.S. van Asbeck, J.P. Neijt, and J.J. Marx. 1992. Increased hydrogen peroxide concentration in human tumor cells due to a nitroxide free radical. Bioch. Biophys. Acta. 1136:113-118.

35. Soares, F.A., S.G. Shaughnessy, W.R. MacLarkey, and F.W. Orr. 1994. Quantification and morphologic demonstration of reactive oxygen species produced by Walker 256 tumor cells in vitro and during metastatsis in vivo. $L a b$. Invest. 71:480-489.

36. Shima, D.T., U. Deutsch, and P.A. D'Amore. 1995. Hypoxic induction of vascular endothelial growth factor (VEGF) in human epithelial cells is mediated by increases in mRNA stability. FEBS Lett. 370:203-208.

37. Chomczynski, P., and N. Sacchi. 1987. Single-step method of RNA isolaiton by guanidium thiocyanate-phenol-chloroform extraction. Anal. Biochem. 162:156-159.

38. Yeo, K.T., H.H. Wang, J.A. Nagy, T.M. Sioussat, S.R. Ledbetter, A.J. Hoogewerf, Y. Zhou, E.M. Masse, D.R. Senger, H.F. Dvorak et al. 1993. Vascular permeability factor (vascular endothelial growth factor) in guinea pig and human tumor and inflammatory effusions. Cancer Res. 53:2912-2918.

39. Yeo, K.T., T.M. Sioussat, J.D. Faix, D.R. Senger, and T.K. Yeo. 1992 Development of time-resolved immunofluorometric assay of vascular permeability factor. Clin. Chem. 38:71-75.

40. Nayak, M.S., M. Kita, and M.F. Marmor. 1993. Protection of rabbit retina from ischemic injury by superoxide dismutase and catalase. Invest. Ophthalmol. Visual Sci. 34:2018-2022.

41. Gelbach, P.L., and R.L. Purple. 1994. A paired comparison of two mod- els of experimental retinal ischemia. Curr. Eye Res. 13:597-602.

42. Maki, A., I.K. Berenzesky, J. Fargnoli, N.J. Holbrook, and B.F. Trump. 1992. Role of $\left[\mathrm{Ca}^{2+}\right]$ in induction of c-fos, c-jun and c-myc mRNA in rat PTE after oxidative stress. FASEB (Fed. Am. Soc. Exp. Biol.) J. 6:919-924.

43. Adamis, A.P., D.T. Shima, T.K. Yeo, L.F. Brown, B. Berse, P.A D'Amore, and J. Folkman. 1993. Synthesis and secretion of vascular permeability factor/vascular endothelial growth factor by human retinal pigment epithelial cells. Biochem. Biophys. Res. Commun. 193:631-638.

44. McCord, J.M. 1985. Oxygen-derived free radicals in postischemic tissue injury. N. Engl. J. Med. 312:159-163.

45. Romson, J.L., B.G. Hook, S.L. Kunkel, G.D. Abrams, A. Schork, and B.R. Bucchesi. 1983. Reduction of the extent of ischemic myocardial injury by neutrophil depletion in the dog. Circulation. 67:1016-1023.

46. Boveis, A. 1977. Mitochondrial production of superoxide radical and hydrogen peroxide. Adv. Exp. Med. Biol. 78:67-82.

47. Kuzuya, T., S. Hoshida, Y. Kim, H. Oe, M. Hori, T. Kamada, and M Tada. 1993. Free radical generation coupled with arachidonate lipoxygenase reaction relates to reoxygenation induced myocardial cell injury. Cardiovasc. Res. 27:1056-1060.

48. Grisham, M.B., L.A. Hernandez, and D.N. Granger. 1986. Xanthine oxidase and neutrophil infiltration in intestinal ischemia. Am. J. Physiol 251:567-574

49. McCord, J.M. 1993. Human diseae, free radicals, and the oxidant/antioxidant balance. Clin. Biochem. 26:351-357.

50. Akeo, K., S.A. Curran, and C.K. Dorey. 1988. Superoxide dismutase activity and growth of retinal pigment epithelial cells are supressed by $20 \%$ oxygen in vitro. Curr. Eye Res. 7:961-967.

51. Franceschi, D., and D. Graham. 1990. Mechanisms of oxygen free radical-induced calcium overload in endothelial cells. Surgery (St. Louis). 108:292-297.

52. Shibnuma, M., T. Kuroki, and K. Nose. 1988. Superoxide as a signal for increase in intracellular pH . J. Cell. Physiol. 136:379-383.

53. Rao, G.N., and B.C. Berk. 1991. Active oxygen species stimulate vascular smooth muscle cell growth and proto-oncogene expression. Circ. Res. 70:15-24.

54. Schreck, R., K. Albermann, and P.A. Baeurle. 1992. Nuclear factor kB an oxidative stress-responsive transcription factor of eukaryotic cells (a review). Free Rad. Res. Comms. 17:221-237.

55. Vercellotti, G.M., S.P. Serveso, P. Duane, and C.F. Moldow. 1991. Hydrogen peroxide alters signal transduction in human endothelial cells. $J . L a b$. Clin. Med. 117:15-24.

56. Deforge, L.E., A.M. Preston, E. Takeuchi, J. Kenney, L.A. Boxer, and D.G. Remick. 1993. Regulation of interleukin 8 gene expression by oxidant stress. J. Biol. Chem. 268:25568-25576.

57. Sundaresan, M., Z. Yu, V.J. Ferrans, K. Irani, and T. Finkel. 1995. Requirement for generation of $\mathrm{H}_{2} \mathrm{O}_{2}$ for platelet-derived growth factor signal transduction. Science (Wash. DC). 270:296-299.

58. Miceli, M.V., M.R. Liles, and D.A. Newsome. 1994. Evaluation of oxidative processes in human pigment epithelial cells associated with retinal outer segment phagocytosis. Exp. Cell Res. 214:242-249.

59. Banai, S., D. Shweiki, A. Pinson, M. Chandra, G. Lazarovici, and E. Keshet. 1995. Upregulation of vascular endothelial growth factor expression induced by myocardial ischemia: implications for coronary angiogenesis. Cardiovasc. Res. 28:1176-1179.

60. Roberts, W.G., and G.E. Palade. 1995. Increased capillary permeability and endothelial fenestration induced by vascular endothelial growth factor. Mol. Biol. Cell. 108:2369-2379. (Abstr.)

61. Flick, M.R., J. Hoeffel, and N.C. Staub. 1981. Superoxide dismutase prevents increased lung vascular permeability after air emboi in un-anesthetized sheep. Fed. Proc. 40:405-410.

62. Parks, D.A., G.B. Bulkley, D.N. Granger, S.R. Hamilton, and J.M. McCord. 1982. Ischemic injury in the cat small intestine: role of superoxide radicals. Gastroenterology. 82:9-15.

63. Ikeda, E., M.G. Achen, G. Greier, and W. Risau. 1995. Hypoxia-induced transcriptional activation and increased mRNA stability of vascular endothelial growth factor in C6 glioma cells. J. Biol. Chem. 270:19761-19766.

64. Stein, I., M. Neeman, D. Shweiki, A. Itin, and E. Keshet. 1995. Stabilization of vascular endothelial growth factor mRNA by hypoxia and hypoglycemia and coregulation with other ischemia-induced genes. Mol. Cell. Biol. 14:53635368 .

65. Hasegawa, K., H. Yoshioka, T. Sawada, and H. Nishikawa. 1993. Direct measurement of free radicals in the neonatal mouse brain subjected to hypoxia: an electron spin resonance spectroscopic study. Brain Res. 607:161-166.

66. Youngson, C., C. Nurse, H. Yeger, and E. Cutz. 1993. Oxygen sensing in airway chemoreceptors. Nature (Lond.). 365:153-155.

67. Colton, T. 1974. Statistics in Medicine. Little, Brown \& Co. Inc. Boston, MA. $131 \mathrm{pp.}$ 